ARTICLE

DOI: $10.1057 /$ s41599-017-0043-y

\title{
The first vampire films in America
}

\author{
Gary D. Rhodes ${ }^{1}$
}

\begin{abstract}
Horror film scholarship has generally suggested that the supernatural vampire either did not appear onscreen during the early cinema period, or that it appeared only once, in Georges Méliès' Le manoir du diable/The Devil's Castle (1896). By making rigorous use of archival materials, this essay tests those assumptions and determines them to be incorrect, while at the same time acknowledging the ambiguity of vampires and early cinema, both being prone to misreadings and misunderstandings. Between 1895 and 1915, moving pictures underwent major evolutions that transformed their narrative codes of intelligibility. During the same years, the subject of vampirism also experienced great change, with the supernatural characters of folklore largely dislocated by the non-supernatural "vamps" of popular culture. In an effort to reconcile the onscreen ambiguities, this paper adopts a New Film History methodology to examine four early films distributed in America, showing how characters in two of them-Le manoir du diable and La légende du fantôme/Legend of a Ghost (Pathé Frères, 1908) have in different eras been mistakenly read as supernatural vampires, as well as how a third-The Vampire, a little-known chapter of the serial The Exploits of Elaine (Pathé, 1915) invoked supernatural vampirism, but only as a metaphor. The paper concludes by analyzing Loïe Fuller (Pathé Frères, 1905), the only film of the era that seems to have depicted a supernatural vampire. Revising the early history of vampires onscreen brings renewed focus to the intrinsic similarities between the supernatural creatures and the cinema.
\end{abstract}

\footnotetext{
${ }^{1}$ Queen's University, Belfast, United Kingdom. Correspondence and requests for materials should be addressed to G.D.R. (email: gdrhodes@gmail.com)
} 


\section{Introdution}

n Bram Stoker's Dracula (1992), Francis Ford Coppola depicts Count Dracula (Gary Oldman) walking through London in grainy footage that appears to have been shot at 16 or 18 frames per second. The sound of a film projector can be heard in the background, as can a street barker inviting passersby to "see the amazing Cinématographe." Dracula and Mina (Winona Ryder) attend the performance, with the moving pictures arousing the vampire's bloodlust. On two occasions, a stark and phantom-like train appears onscreen behind the Count; Coppola created these images for his film, inspired by such films as L'arrivée d'un train en gare de La Ciotat/Arrival of a Train at the Station (Lumière, 1895) and The Ghost Train (American Mutoscope and Biograph, 1901) (Cordell, 2013, p 1). Here Coppola links vampirism and the cinema, in part because Stoker's novel was published in 1897, at roughly the same time that public film projections became common.

But there is potentially another, deeper link between the cinema and the supernatural. "Last night I was in the Kingdom of Shadows," Maxim Gorky famously recounted after visiting a Lumière film screening in July 1896. "If you only knew how strange it is to be there," he wrote:

It is not life, but life's shadow, it is not motion, but its soundless spectre.... It is terrifying to see, but it is the movement of shadows, only of shadows. Curses and ghosts, the evil spirits that have cast entire cities into eternal sleep, come to mind... (Harding, p 5).

Gorky was not alone in likening moving pictures to the supernatural. Woodville Latham and his sons might well have considered that metaphor while inventing their "Eidoloscope," which Musser (1990a) has called "the first American machine for projecting motion pictures" (p 91). Their projector made its public debut in April 1895. It was named after the "eidolon" of Greek literature, meaning a phantom, spectre, or spirit-image of a person. Less than six months later, in September 1895, C. Francis Jenkins and Thomas Armat premiered their own invention, America's first commercially viable projector using an intermittent mechanism. They called it the Phantoscope (Musser, 1990a, p 103). On October 3, 1895, the Baltimore Sun called it "mysterious" (p 2).

Perceived connections between vampirism and early and silent cinema continue to resonate. E. Elias Merhige's Shadow of the Vampire (2000), a fantastical account of the making of Nosferatu (1922), features Willem Dafoe as actor Max Schreck. In this alternate history, Schreck is an actual vampire, hired by director F. W. Murnau (John Malkovich) to add realism to his motion picture. In one scene, Schreck becomes fascinated by a film projector, peering into its lens, the light flickering on his face. He has become projected. Merhige constructs a powerful metaphor, one that bears relation to Coppola's.

One need only consider the question of where cinema resides to understand the potency of these vampiric metaphors. Film is spooled around a reel, but that is not where audience sees it. Rather, light passes through frames separated by black space, pulsing temporally and temporarily on a screen. But even the screen is not a film's permanent home, certainly not in the same way that a frame provides to a painting. The location of a film is in flux. A film is most alive while it is being projected, materialized in the darkness, simultaneously luminous and tenebrous, and that is when it exists between two worlds. Much the same is true of a vampire, its status is difficult to locate, let alone comprehend. To be undead is to be neither alive nor dead, but rather to exist in a strange twilight amid the two, unreal and corporeal at the same time.
To these longstanding comparisons, another should be considered, the notion that-for a variety of reasons during the late nineteenth century and the early twentieth-the cinema and vampirism both underwent various evolutions that impacted heavily on the ability of audiences to comprehend them, to make sense of them. The two regularly pose questions, but those questions are particularly pronounced when considering the period from 1895 to 1915 . To explore this issue, the United States serves as an important case study, as it represents a geographical location in which these issues at times collide and at times converge. The protean vampire was never more instable than in America during those years.

Here the question is whether or not the undead walked onscreen in early cinema. Consider Stacey Abbott's monograph Celluloid Vampires: Life after Death in the Modern World (2007), in which she writes the "vampire was absent from the early days of cinema" ( $p$ 44), after having already announced, "French magician and filmmaker Georges Méliès brought forth the first celluloid vampire in his [1896] film Le manoir du diable" (1), but prior to describing the character in that same film as a "satanic figure" ( $p$ 50). It is not the apparent contradiction in these comments that is important, but instead the reasons for the confusion that exist in the archive and in the scholarship.

Nowhere are these issues more pronounced than in four moving pictures produced between 1896 and 1915, all of them screened in the United States: Le manoir du diable/The Devil's Castle (Georges Méliès, 1896), which modern critics have sometimes mistaken as a supernatural vampire film; La légende $d u$ fantôme/Legend of a Ghost (Pathé Frères, 1908, aka The Black Pearl), which one American critic in 1908 mistook as featuring a supernatural vampire; The Vampire, episode six of the serial The Exploits of Elaine (Pathé, 1915), which invoked supernatural vampirism, but only to deploy it as a metaphor; and Lö̈e Fuller (Pathé Frères, 1905), which featured what might well have been intended to be a supernatural vampire.

These case studies allow consideration of what the earliest vampire films were, or at least might have been, an important pursuit given scholarly interest in early cinema and horror studies. It is as easy to be as excited by the vampire in early cinema as Coppola was. However, these four films also allow us to explore the paradoxical nature of vampires and early cinema. At times, both are murky, their images fleeting and indistinct, their stories needing to be read, but always at the risk of being misread.

\section{Ambiguity}

In addition to her comments on the vampire in early cinema, Abbott informs readers that Nosferatu (Murnau, 1922) represented the "cinema's first entirely cinematic vampire, drawing upon the ambiguity between the living and the dead, the scientific and the fantastic" (p 44-45). Her argument has much merit, founded as it is upon the types of ambiguities that Coppola earlier explored in Bram Stoker's Dracula and that should be observed when examining vampirism and early cinema. Consider the following account from Rhode Island, published in the Tacoma News on March 28, 1896, only days before Edison's Vitascope premiered at Koster and Bial's in New York City:

It gives one a creeping sensation of horror to think that in enlightened New England, during the final decade of the nineteenth century, the corpse of a young woman buried eight weeks was dug out of the ground, the heart and liver cut out and burned, and all this that the dead might cease to be nourished at the expense of living relatives (p 3). 
In this case, the understanding of and belief in supernatural vampires was so strong that a suspected corpse was exhumed. The incident stemmed from established and readily understood superstitions. As early as June 15, 1732, the American Weekly Mercury published a non-fiction account about Hungary that claimed "certain Dead Bodies (called here Vampyres) killed several persons by sucking out all their blood" (p 2). During the nineteenth century, Americans learned about vampires from the increasing role that such they played in fictional literature and entertainment, including in the notable cases of John Polidori's 1819 short story The Vampyre, A Tale and James Robinson Planché's 1820 play The Vampyre; or, The Bride of the Isles (aka The Vampire, or the Bride of the Isles), which was staged repeatedly in the decades after its premiere.

However, in 1897, Philip Burne-Jones's painting The Vampire, and Rudyard Kipling's companion poem of the same name, recast the supernatural creature as a mortal woman who metaphorically bleeds men of their lives. The effect on popular culture was so robust that many persons were no longer certain as to what a vampire was. For some, the term became plural, indicative of old superstitions and recent art. For others, the new definition dispossessed the old, despite the success of Bram Stoker's novel Dracula (1897), first published in America in 1899.

The impact of the Burne-Jones painting and Kipling's poem on American usage of the term "vampire" had an immediate and profound effect. On March 5, 1899, a journalist in the New York Times reported:

People nowadays carelessly use the word 'vampire' as a stronger and trifle more loathsome term than 'parasite.' Burne-Jones once painted a picture called the Vampire. It was a very beautiful woman leaning over a man she had just slain. And Kipling wrote some symbolic verses about it (IMS2).

The journalist added his view that "Probably few persons know what the real vampire is," the Burne-Jones depiction having so quickly displaced the supernatural character in much of popular culture.

Indeed, despite the success of Stoker's novel, the foremost understanding of vampirism in America in the early twentieth century remained the Burne-Jones and Kipling character. Consider this article published in the Chicago Tribune article in January 25, 1903:

'What is a vampire, anyway?' asked a young woman looking at the Burne-Jones picture now on exhibition.

'A vampire,' [replied] her companion. 'A vampire is the rag and a bone and a hank of hair that Kipling talks about.'

They probably had not spent a portion of their youthful lives in a small town visited occasionally by the "greatest show on earth' with its sideshow. If they had they would have known all about the 'blood sucking vampire.' They would have dreamed about it... (p 40).

Exasperated by cultural confusion over the term, the journalist felt compelled to describe supernatural vampires in great detail, both in their folkloric roots and in Stoker's novel, all in an effort to (re-) educate at least some Americans.

Nevertheless, the Burne-Jones vampire continued to dominate American popular culture thanks in large measure to Porter Emerson Browne's 1909 novel A Fool There Was, which he quickly adapted for the stage. In 1910, Selig Polyscope produced the moving picture The Vampire, which attempted to bring the Burne-Jones painting to life and even quoted Kipling in its intertitles. A large number of "vamp" films followed, with A Fool
There Was (Fox, 1915) starring Theda Bara being the most famous. Not surprisingly, when David McKay published the first American edition of Dudley Wright's book Vampires and Vampirism in 1914, it was necessary to begin with the question: "What is a vampire?" (Wright, 2001, p 1).

Questions of meaning and legibility are also crucial in the viewing of early cinema, its film content striking some later viewers as so distinct from the Classical Hollywood Style as to suggest an avant-garde. For example, the Bruce Posner-curated DVD collection Unseen Cinema: Early American Avant-Garde Film, 1894-1941 features many moving pictures produced before 1915, including by such mainstream companies as the Edison Manufacturing Company and American Mutoscope \& Biograph. Kristin Thompson (1995) has argued that it is "only after the formulation of classical Hollywood norms was well advanced that we can speak of an avant-garde alternative" (p 68). But whether one views a term like "avant-garde" to be a modern imposition on early cinema or whether one concentrates on-as Bart Testa (1992) sees it—the "back and forth" interactions between early cinema and later avant-garde films that appropriated footage from the period, the discussion must consider that some early film narratives are opaque, if not obscure. Their "codes of intelligibility," as Thomas Elsaesser (1990b, p 11) calls them, can pose challenges for modern audiences, just as they did for some of their original viewers.

Tom Gunning, André Gaudreault, Charles Musser, and others who have analyzed early cinema narratives have appropriately complicated the period, observing different and evolving narrative patterns. Gunning (1990a) believes the earliest films represented a "cinema of attractions," meaning not only that film exhibitions were themselves attractions (including in terms of the demonstration of projection equipment), but also that, during its early years, the cinema tended to focus on the presentational and the spectacular in order to incite "visual curiosity" and supply visual "pleasure" (p 56). As Gunning (1990b) writes, "this cinema differs from later narrative cinema through its fascination in the thrill of display rather than its construction of a story" (p 100). Narrative storylines were minimal, and so the possibility for them to be misread was very real.

Gunning (1990a) originally suggested that the period from 1907 to approximately 1911 "represents the true narrativization of the cinema" (p 60). In his later work (1993), he augmented that view by noting the cinema of attractions predominated until circa 1903, followed by a period of transition that lasted until circa 1908 (p 10-11). At no other period during the history of American film did greater change occur, unfolding, as Elsaesser (1990a) has observed, not as a linear progression, but in "in leaps; not on a single front, but in more jagged lines and waves: this history of film form emerges as a complicated transformational process involving shifts in several dimensions" (p 408).

As the early cinema period progressed, film narratives became simultaneously more complicated and more legible. For example, Gunning's 1991 monograph on D.W. Griffith includes a chapter entitled "Complete and Coherent Films, Self-Contained Commodities," which argues the "narrator system ... came into focus" by the end of 1908 ( $p$ 130). That said, audiences still experienced occasional difficulty in comprehending given film narratives. On January 7, 1911, a journalist for the Moving Picture World remarked:

Ambiguity in pictures is one of the chief failures of the day in moving picture subjects; this is evident to the critic and the public. If only the critic experienced this ambiguity, it might become a matter of opinion between keen minds, but when the student of moving pictures finds it difficult sufficiently to grasp the 'plot' or see the 'point,' there is 
further evidence of this weakness ... the public is full of inquiries so that when sitting in the theaters one overhears a constant stream of queries-especially the exclamation at the sudden abrupt or ambiguous ending of a subject (p 14).

The same journalist also recounted such "audible exclamations" from viewers as "What does it mean?" and "Could you understand it?" (p 40).

For Gunning (1990b), early cinema represents a "paradox" in that it is "simultaneously different from later practices-an alternate cinema-and yet profoundly related to the cinema that followed it" (p 102). It is an evolving cinema, and its relationship to later film practices might well be one of the reasons it can be difficult to view intelligibly. Anyone in the twenty-first century struggles to avoid seeing these moving pictures through the lens of post-1915 filmmaking. It is on occasion challenging even for film theorists and historians to read given films from the early cinema period with precision.

The penumbra of vampires that appeared during the years from approximately 1897 to 1915 also represent a paradox, one in which distinctive characters emerge in jagged lines and waves, some supernatural and some not, all as part of a complex transformational process in which-despite their differencesalternate vampires spawned by Burne-Jones and Kipling were profoundly related to those that came before and which would appear later. The result was a complicated and overlapping set of vampire depictions that are also difficult to read, to analyze, to fathom. As Browning and Picart (2009) have observed, "The vampire is a construction that is under continuous development, an assemblage of words, images, and places especially that almost resembles a Frankensteinian creature" (p 17). It is into this Kingdom of Shadows that scholars must venture.

\section{Le manoir du diable/The Devil's Castle (1896)}

Georges Méliès' Le manoir du diable (1896) is a key example of the horror-themed film in early cinema. Its tone is more serious than many of his subsequent films, which generally focussed on humor, and its visual content presents a number of tropes later associated with the horror film genre, among them devils, ghosts, and witches inside a haunted castle. Believed lost for decades, a copy resurfaced in 1988 at the Ngā Taonga Sound \& Vision archive, appearing on the Flicker Alley DVD Georges Méliès Encore in 2010.

In America, Lubin distributed Le manoir du diable as The Devil's Castle; Edison released it as The Infernal Palace (Edison Films, No. 94, 1900, p 39-40). When American audiences first saw it is difficult to determine. The film appears in American Vitagraph's 1900 List of New Films, which offered it in three lengths, meaning 50, 100, or 200 feet (p 2). However, newspaper advertisements as early as 1899 list Lubin's title being screened at moving picture exhibits. For example, on April 2, 1899, an advertisement in the New York Times for Huber's Museum publicized the "Historiograph" on a bill with live entertainment made up of: "Royal Japanese Wrestlers and Acrobats, Great Success of Allini's Monkeys, Boxing Bouts, Wire Walking, and Trapeze Performance" ( $p$ 17). The Historiograph was to present 25 minutes of moving pictures, but The Devil's Castle-which the ad promised would be screened "complete in every detail" ( $p$ 17) - was the only one that was named.

Later that same month, the Ninth and Arch Museum in Philadelphia featured a vaudeville show that ended with the "Cineograph" moving pictures. Foremost among the group were two Méliès films, L’homme dans la lune/A Trip to the Moon (1899, aka Astronomer's Dream) and The Devil's Castle. An advertisement published in the Philadelphia Inquirer on April 30, 1899 touted the duo as "the most striking moving pictures ever

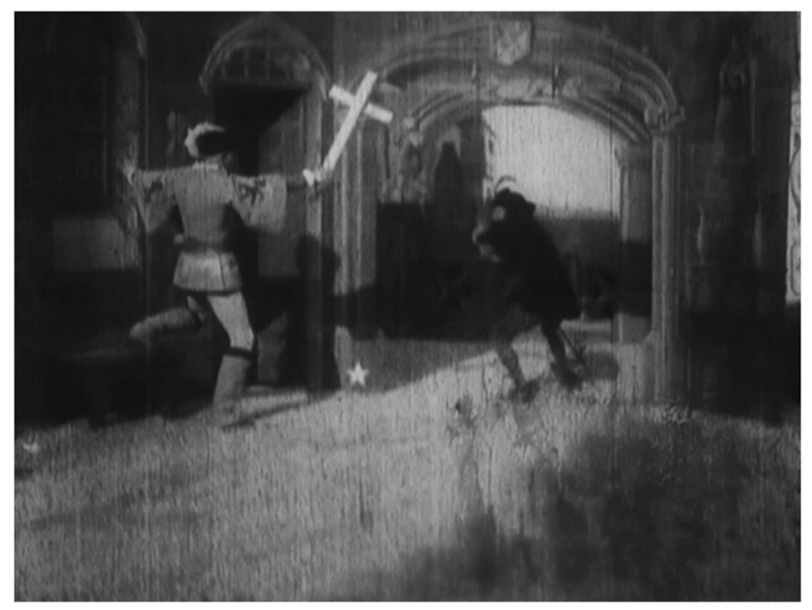

Fig. 1 A frame from Georges Méliès' Le manoir du diable (1896). A crucifix is used to dispel the film's devil. As this work was published before 1923, it is in the public domain. This figure is covered by the Creative Commons Attribution 4.0 International License

taken" (p 12). In yet another indication of its apparent popularity, an article on film piracy printed in the Davenport Weekly Leader on June 7, 1901 specifically cited The Devil's Castle as one of six Méliès films that had been illegally duped. The culprits included Lubin, who continued to sell the film in his catalogs until as late as 1908 (Lubin's Films, 1908, p S6).

Along with Stacey Abbott, numerous writers in the modern era have referred to The Devil's Castle as-to use the words of J. Gordon Melton (2011)—the "very first vampire film" (p 448). Such a judgment appears in monographs, academic papers, and vampire-related websites. ${ }^{1}$ Nowhere is this more evident than in the title of John L. Flynn's 1992 book Cinematic Vampires: The Living Dead on Film and Television, from The Devil's Castle (1896) to Bram Stoker's Dracula (1992). But however crucial Méliès' moving picture was, with all the many horror conventions it introduced to cinema, no vampires appear during its running time. There are ghosts and witches, a devil and an imp, but no vampires. None whatsoever.

To begin, the film's original title and most common English translation indicate that the key villain depicted is a devil, not a vampire. $^{2}$ Méliès reiterates this point in the character's appearance: the devil's costume features pronounced fabric horns, much as stage productions of Faust had done throughout the nineteenth century. Film catalogs reinforce this interpretation. In 1900, Edison Films, No. 94 described its climax as follows: "Finally one of the cavaliers produces a cross, and Mephistopheles throws up his hands and disappears in a cloud of smoke" (p 40; see Fig. 1). Then, in January 1903, the Complete Catalogue of Lubin's Films said much the same: "Satan... vanishes immediately when the Cross $[s i c]$ is held before him" (p 20).

During the era of sound cinema, the use of a cross to dispel vampires became so common as to obscure the fact that the same religious iconography had been used in an earlier age to dispel devils. Consider the short story A Ghost, published in the Connecticut Gazette on August 30, 1797, in which the narrator tells us: "At length I concluded, if it be a demon, he will fly at the sign of the cross" (p 1). This was also true, for example, in the ballet Uriella, the Demon of the Night, which was staged in New York in 1870. It was also true in early cinema. In Le fils du diable/ Mephisto's Son (Pathé Frères, 1906), the son of Satan cowers before a priest carrying a cross. On October 3, 1908, Moving Picture World told readers that, in Vitagraph's The Gambler and the Devil (1908), the female lead "holds up a cross before him. 


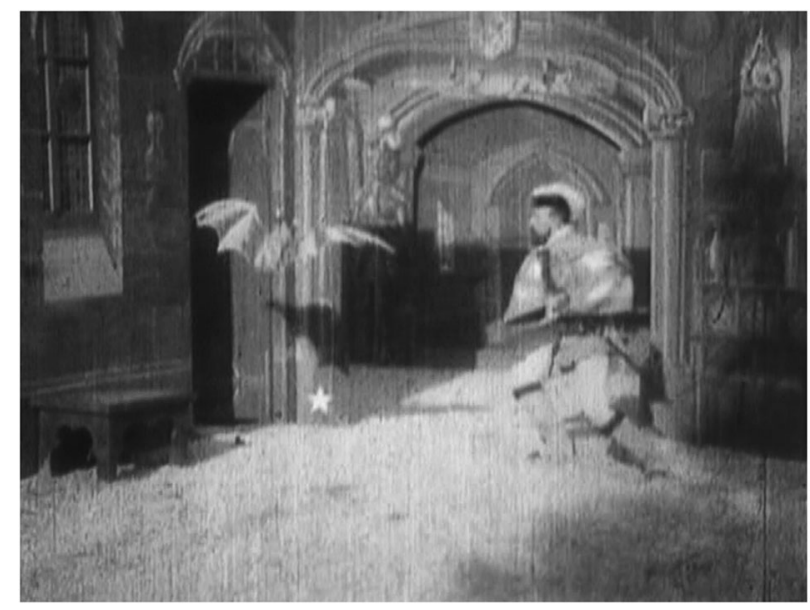

Fig. 2 A frame from Georges Méliès' Le manoir du diable (1896). The devil appears in the form of a bat. As this work was published before 1923, it is in the public domain. This figure is covered by the Creative Commons Attribution 4.0 International License

The devil covers his eyes with his hands, there is a puff of smoke, and he disappears" (p 267). Then, on March 18, 1911, the same publication wrote that, in La défaite de Satan/Satan Defeated (Pathé Frères, 1910), a character "holds up the crucifix and Satan disappears forever" ( $p$ 602).

If the use of the cross is one reason that modern viewers have mistaken the devil character for being a vampire, the other is film's opening, in which a large bat transforms into Mephistopheles (Fig. 2). Here again, the emphasis in vampire literature and films of the post-1896 era have clouded the ability for modern viewers to read The Devil's Castle as it was intended. Indeed, even though he acknowledges the character is Mephistopheles and not a vampire, Stephen Prince (2004) still refers to the prop as a "vampire bat" ( $\mathrm{p} 1$ ), when there is no historical or textual reason to suggest the bat is or was specifically meant to be a vampire bat.

Satan is not a vampire, but prior to 1896 there is a lengthy history that gives him demonic wings or even likens him to a bat. It is important to recall Ephesians 2:2, which describes Satan as the "prince of the power of the air." To enumerate the sheer volume of artwork over the centuries that depicts devils and demons as having bat-like wings and talons would be difficult. Famous examples include Botticelli's and Doré's illustrations for Dante's Inferno, as well as Doré's engravings for Milton's Paradise Lost. The same is true in late nineteenth-century visual culture, including in many French "diablerie" stereographs (Borton and Borton, 2014, p 139).

Here again the same can be identified repeatedly in early cinema, including in Méliès' Le diable au couvent/The Devil in the Convent (Méliès, 1900, aka The Sign of the Cross; or the Devil in a Convent), in which Satan flies into the convent, and in Méliès' Le Chevalier des Neiges/The Knight of the Snow (1912), in which a bat emblem appears on the devil's shirt, as well as on a large banner behind him. But the imagery was hardly unique to Méliès. An advertisement for the Italian-made Satana, ovvero il dramma dell'umanità/Satan, or, The Drama of Humanity (Ambrosio, 1912) published on January 11, 1913 in the Moving Picture World used artwork of a bat to promote a film about the devil's negative impact on humankind. No narrative or visual cues in these cases suggest such wings or bats have any affiliation with vampirism or, for that matter, that the bats depicted are specifically vampire bats.

Given that The Devil's Castle was hardly unique in its treatment of Satan, the film's meaning was probably unambiguous to original audiences. But that has not proven true of modern viewers, who have imposed their awareness of later Hollywood vampire cinema onto Méliès, seeing a vampire where one did not exist. A key way to understand and correct this error is to consider Charles Musser's research on Edwin S. Porter's The Great Train Robbery (Edison, 1903), a film regularly cited as the first, or one of the first, westerns. Perceiving this to be a "retrospective reading," one that positions the film within a film genre that did not yet exist, Musser examines The Great Train Robbery in relation to moving pictures that preceded it, specifically in "its ability to incorporate so many trends, genres and strategies fundamental to the institution of cinema at the time" (1990b, p 130). ${ }^{3}$ These included the travel genre (specifically the railway subgenre), the genre of re-enacted news events, and the crime genre. ${ }^{4}$ The Devil's Castle likewise integrated characters and narrative concerns that preceded it, none of them involving supernatural vampires.

\section{La légende du fantôme/Legend of a Ghost (1908)}

If one person became Georges Méliès' immediate heir, it was Segundo de Chomón, a Spanish filmmaker whose expertise with coloring moving pictures gained him work at Pathé Frères in 1905. He became "one of the main supervisors (and shortly after, the manager) of the company's trick film section" (Batllori, 2009, p 97). In many ways, his narrative and aesthetic approach intentionally mimicked Méliès; in 1908, for example, he remade Méliès' Le Voyage dans la lune/A Trip to the Moon (1902) as Excursion dans la lune/An Excursion to the Moon (Pathé Frères, aka Excursion to Moon). ${ }^{5}$ But in other respects, Chomón advanced the trick picture, including in his expert use of color and animation.

Of particular importance is the fact that Chomón at times used tricks to construct dramatic, horror-themed storylines, most notably in the hand-colored La légende du fantôme/Legend of a Ghost (Pathé Frères, 1908). ${ }^{6}$ Here is a key link in the evolution of the horror-themed moving picture, with the attraction of cinematic tricks logically embedded into a dramatic narrative, one inspired by Dante's Inferno and the Greek myth of Orpheus. How American audiences reacted at the time is hard to determine, but on May 23, 1908, Variety praised the film's "curious, mystic light effects," which were "well handled to heighten the weirdness of the scenes" (p 12).

For at least one person in 1908, Legend of a Ghost depicted a supernatural vampire. According to a plot synopsis published in Moving Picture World on May 23, 1908:

Arriving at the gate of Satan's kingdom, they mount a chariot of fire and, arriving at the devil's palace, give fight to the demons mounting guard over their king, and after having defeated them, rush into the palace. Now Satan, seeing his life in peril, disappears in a cloud of smoke and thunder, and is seen again as he dashes through his vast domains gathering together his people, and while they await the conquering chariot another fight ensues. The devil is beaten again and the bottle of life is stolen by the leader of the victorious army, and they are all about to depart when a terrible explosion takes place and the chariot and its occupants are dashed to the ground. All are killed but the brave woman who undertook the expedition, and she goes forth alone... (p 463).

The synopsis - which was also printed in Views and Film Index on the same day - continues with explicit mention that "dragons and vampires" attempt "to stop her progress towards earth." 
This seems to be the earliest mention in the American press of a moving picture featuring a supernatural vampire, the synopsis writer presumably being someone working for Pathé Frères in the United States. But viewing the film, which survives, makes clear why synopses published in other countries did not mention vampires. Nor did the aforementioned review published in Variety. The young lady's difficult journey back to the surface features characters that at first appear similar to dragons, but a careful examination of the mise-en-scène-which includes seashells and marine plants-indicates they were likely intended to be sea creatures.

This case seems to be the reverse of The Devil's Castle, in that a period viewer (presuming the synopsis writer actually viewed the film) mistook onscreen characters for vampires when no one else has, either at the time (so far as can be determined) or in the modern era. However, here the error is potentially more complicated than what amounts to retrospective misreadings of The Devil's Castle. The viewer might well have found Legend of a Ghost ambiguous (particularly insofar as not understanding scenes intended to be underwater), and also found vampires to be ambiguous, not understanding what they looked like or how they should appear, whether in a film or otherwise, and thus confusing the same with a sea creature. The ambiguity of vampirism and early cinema had thus converged.

\section{The Exploits of Elaine (1915)}

One film that explicitly referred to supernatural vampirism during the early cinema period was a movie serial. As Ben Singer (2001) explains, "sensational melodrama" was prominent in emergent feature films of the 1910s, but it was in "serial films that the genre really flourished" ( $p$ 198). Even though the emphasis of early movie serials was on melodramatic action, their narrative content, chapter titles, and publicity at times drew upon horror themes, ranging from their imperiled heroines to their dastardly villains.

Episode six of the serial The Exploits of Elaine (Pathé, 1915) was titled The Vampire. In it, Elaine (Pearl White) shoots an underling of her nemesis, "The Clutching Hand" (Sheldon Lewis). The only way to save his life is a blood transfusion. According to a plot synopsis published in Motography on February 14, 1915, the insidious villain:

thereupon sees an opportunity of killing two birds with one stone, that is, to save his tool's life and destroy that of Elaine. He sends two accomplices to Elaine's home, chloroforms her, and confines her within a suit of armor which stands in the reception room of her own home. The next morning an expressman is sent for this suit of armor, which has been damaged and orders repairing which [has] been given, and thus the helpless Elaine is boldly kidnapped in broad daylight, and taken to the Clutching Hand's abode. There her arm is bared, strapped to that of the wounded man, and the great doctor prepares to perform the critical operation (p 243).

The police rescue Elaine, halting the operation and saving her life, even as the underling "breathes his last almost immediately afterwards" ( $p$ 243). The Clutching Hand escapes from the authorities thanks to a sliding panel in the wall.

On February 13, 1915, Moving Picture World promised readers that the episode would make viewers' "nerves creep at the uncanny ability of the terrible band and the blood boil at the audicity of the leader of it" ( $p$ 987). The episode was intended to frighten audiences, at least in part. The trade added, "This is an unusual situation and we suspect that no one has ever used it before-be it remembered that no one sees all pictures" ( $p$ 987).
What exactly was the unusual situation? Moving Picture World presumably meant a story in which the villain tries to force the heroine into giving blood to save another villain. In other words, any initial excitement at reading the words "vampire and "blood" must be tempered by a careful reading of the synopsis. In this case, "The Vampire" is the non-supernatural villain The Clutching Hand. While a novelty in the cinema, the story had roots in nineteenth-century fiction.

In Hawley Smart's dime novel The Vampire; Or, Detective Brand's Greatest Case (1885), murder victims are found with two punctures on their neck. At first, it seems a vampire is on the loose, one "who leads an artificial life-who lives on the blood he extracts from his victims-that he sucks from their very veins, drawing the red life-current directly from the heart." But the solution to the mystery rationalizes the supernatural. As the murderer confesses, "My particular craze, when the fit came on, was to believe I was a vampire, one of those fabulous creatures who lives on human blood. I slew my victims, and then I pricked them in the neck with the dagger point, just as if the vampire's teeth had bitten them." But vampire's teeth had not bitten them, no more than The Clutching Hand took a bite out of Elaine. As Thomas Leitch has written in his study of vampire adaptations:

... authorship is always collaborative because every author depends on the assistance, example and provocation of innumerable predecessors and contemporaries, acknowledged or concealed, if only because every mode of communication by its nature involves the sharing of knowledge (2011, p 11-12).

Knowingly or not, in other words, episode six of The Exploits of Elaine conjured earlier stories of the type Hawley Smart wrote, and by extension the fantastical literature of so many other authors, ranging from Ann Radcliffe and Charles Brockden Brown to Washington Irving and Edgar Allan Poe, in which the supernatural seems to be at play, but is not.

Vampire scholars have not discussed or analyzed The Vampire that menaced serial heroine Elaine. While period synopses clearly indicate its reference to supernatural vampirism, both in its chapter title and in its plotline, movie serials of the $1910 \mathrm{~s}$ have not been properly catalogued and remain under-researched. The episode title The Vampire languishes in relative obscurity, certainly to those investigating vampirism in the cinema, despite the fact that copies of it are archived at the George Eastman House, at the Museum of Modern Art, and at Library and Archives Canada.

The question remains as to how best to interpret and classify The Vampire. Its use of supernatural vampirism as a metaphor is undeniable, but how distinctive or unique that was is quite debatable. After all, Burne-Jones and Kipling used vampirism as a metaphor as well, as did all of the many aforementioned films featuring "vamps" (though some more explicitly than others).

The Exploits of Elaine offers a different kind of a metaphor, but still just a metaphor, one partially inspired by a body of works that, not unlike like Hawley Smart's novel, had used the term "vampire" to describe certain kinds of thieves, criminals, and pirates. The most famous example would become Louis Feuillade's French film serial Les Vampires (1915-16), which was distributed in the United States. However, prior to its American release were such films as Les Vampires de la côte/Vampires of the Coast (Pathé Frères, 1909), The Forest Vampires (Domino, 1914), Vampires of the Night (Greene Features, 1914), and Vasco, the Vampire (Imp, 1914): all of them depicted vampires as nonsupernatural criminals and all of them were released in the United States. Much earlier, the play Invisible Prince! Or, the Island of Tranquil Delights, staged in Boston in 1854, featured 


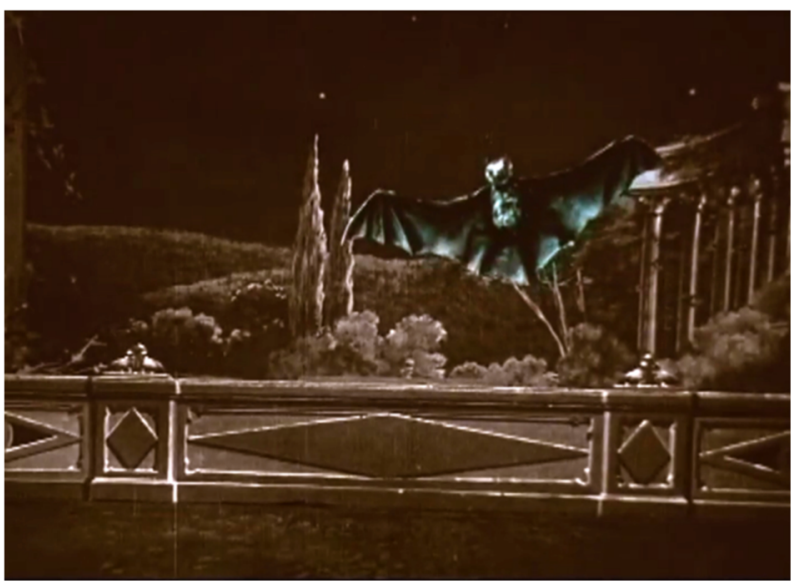

Fig. 3 A frame from Segundo de Chomón's Loïe Fuller (Pathé Frères, 1905). The bat, apparently a vampire bat, appears. As this work was published before 1923, it is in the public domain. This figure is covered by the Creative Commons Attribution 4.0 International License

what one playbill called four "vampire robbers" named Ruffino, Desperado, Sanguino, and Stiletto.

To discover the title The Vampire is not then to discover a supernatural vampire in the cinema, as none appeared during its running time. By contrast, The Vampire offers added insight into the ambiguities and multi-purpose usage of the terminology during the early cinema period. It also signals an important warning for those seeking supernatural vampires onscreen to proceed with appropriate caution.

\section{Loïe Fuller (1905)}

Ten years before audiences saw The Exploits of Elaine, Pathé Frères released Loïe Fuller (1905) in the United States. The director is unknown, although it seems Segundo de Chomón was responsible for its hand-coloring. This French-made film showcased Loïe Fuller, the famous American artist who helped pioneer modern dance. Writing about Fuller's work, Lynda Nead (2007) comments that "astronomy, illumination, cinematography, and the gendered allegorical body" had "come together, finally, in the figure of Loïe Fuller" (p 241). She invented the serpentine dance in 1892 for a New York play about hypnotism, although it achieved its greatest fame soon thereafter at the Folies-Bergère in Paris (Fuller, 1913, p 25-40). Gunning (2003) describes her performances as "visual pyrotechnics created by colored and sharply focused electric light and shadows using the swirling surface of Fuller's fabric as a screen for the projection of an equally protean succession of colors" (p 79). Far more than Max Schreck in Shadow of the Vampire, Fuller was both the project and the projected. The result was an ethereal, even otherworldy performance.

In the film Loïe Fuller, a large bat flies onto the terrace of a country home or a castle, perhaps, as its exterior is not depicted (Fig. 3). A clever transition occurs in which Fuller appears for a moment with the bat on her head (Fig. 4). When the bat disappears, Fuller spreads her costume in bat-wing style, her feet balanced on the terrace ledge before she steps down (Fig. 5). Fuller performs her dance, and then dematerializes thanks to a dissolve, another cinematic sign of her potential supernaturalism.

Why might this character have been understood as a vampire when the character in The Devil's Castle was not, even though both change from bat to human form? Cultural context provides the answer. For one, vampire dance acts became popular in the

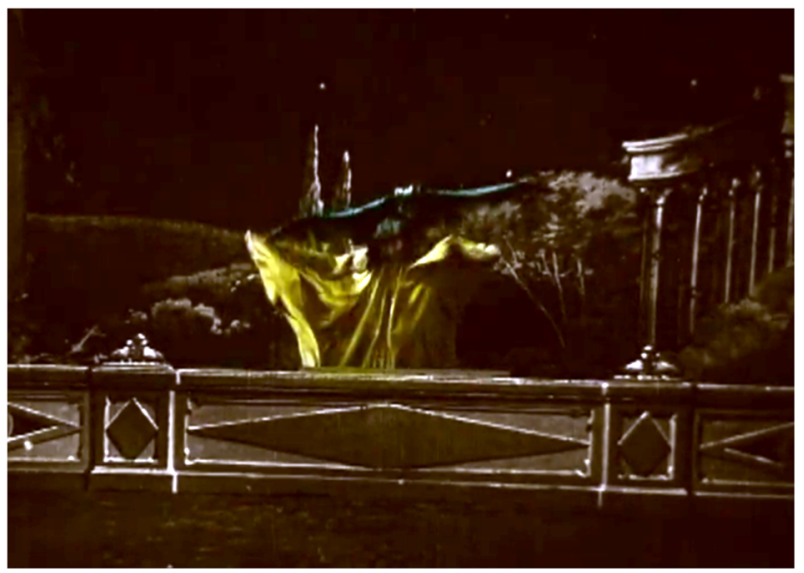

Fig. 4 A frame from Segundo de Chomón's Loïe Fuller (Pathé Frères, 1905). The bat appears on Loïe Fuller's head, as part of the transition. As this work was published before 1923, it is in the public domain. This figure is covered by the Creative Commons Attribution 4.0 International License

fin de siècle. According to an article published in the Charlotte News on October 29, 1890, an American minstrel company offered the "Great Vampire Transformation Dance" (p 4). Whether its transformation involved a bat is unknown, but it is clear that other vampire dances soon followed. In Massachusetts on February 12, 1896, the Springfield Republican reported that a "carnival of holidays" variety show included a "vampire" dance in which performers wore "black gowns with loose skirts, which were ornamented by gilt stars and spangles ( $\mathrm{p} \mathrm{4).} \mathrm{These} \mathrm{dances}$ apparently invoked the supernatural creature, given that they were staged prior to the creation of the Burne-Jones painting and the Kipling poem.

Vampire dances became popular again in 1909, but, by contrast, these later performances were additionally inspired by BurneJones, Kipling, and-perhaps most specifically-the stage play $A$ Fool There Was. At least two men took credit for their invention, one being Tom Terriss, whose dancer was Mildred Deverez. On December 4, 1909, the American Register and Anglo-Colonial World reproduced publicity for Deverez that referred to supernatural vampires as well as those of Burne-Jones-style vamps ( $\mathrm{p} 8$ ). The other person who claimed to be the inventor was Joseph C. Smith. According to the Evening Waterloo Courier of April 23, 1910, his "weird" dance (performed by dancers like Vera Michelena and Violet Dale) depicted vampire and victim in "symbolic postures" on a "darkened stage, with a black background, green spot lights and bars of red light coming from the depths under stage" ( $p$ 12). The male dancer wore black; the vampire wore a "greenish, snake-like clinging gown" (p 12). This type of vampire dance appeared onscreen in August Blom's Vampyrdanserinden/ The Vampire Dancer (Nordisk, 1912), released in America by the International Feature Film Co. The film-which is archived at the Det Danske Filminstitut-was salacious enough to be banned in some U.S. cities. Its provocative dance features a man stumbling into a vamp's lair. She examines him with undisguised lust. He is wary of her. Their movements are slow and sexualized, the vamp first caressing and then gripping his body. The dance culminates with the vamp strangling her partner, smiling wickedly and even kissing him as she does.

More Americans would have seen The Vampire (Kalem, 1913). A synopsis in the Kalem Kalendar of October 1, 1913 notes, the lead character "goes to a theatre where Bert French and Alice Eis are presenting their famous "Vampire Dance"' ( $p$ 15). According to company publicity, French and Eis played themselves in the 


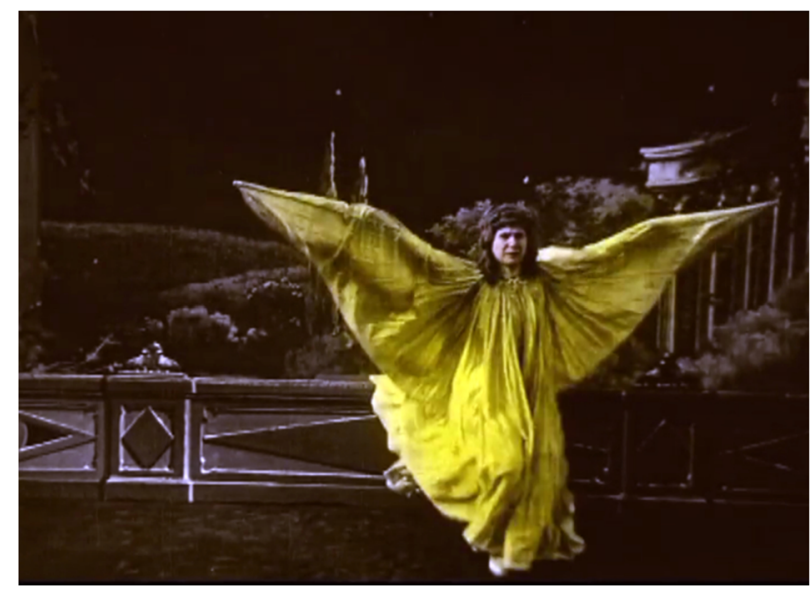

Fig. 5 A frame from Segundo de Chomón's Loïe Fuller (Pathé Frères, 1905). Loïe Fuller with bat wings extended, near the end of the transition. As this work was published before 1923, it is in the public domain. This figure is covered by the Creative Commons Attribution 4.0 International License

film, having performed their dance onstage as early as the summer of 1909. On July 31 of that year, the New York Clipper described their performance as depicting the "woman, youthful and voluptuous, tempting the man, and his final capitulation and death" ( $p$ 637). The dance was, in other words, "taken from Kipling's poem" (p 637). ${ }^{7}$

How much the pre- and post- $A$ Fool There Was vampire dances differed is difficult to determine. Descriptions of those staged during the 1890s are few, but they do suggest similar costumes and imagery appeared in most or all of these dances. By contrast, the reception of the dances might have changed, audiences in 1909 and in the immediate years thereafter understanding them as non-supernatural given the dominant influence of-and, at times, specific reference to-the Burne-Jones/Kipling creation.

In terms of the larger issue of vampire cinema, it seems evident that, in the 1905 film, Loï Fuller-who is in no way garbed as a devil or described as such in the title or in catalog synopses-was performing her own version of a vampire dance. Her bat transformation and dematerialization at the end of the film suggests that she is not merely a female vampire, but a supernatural vampire, which at least some audiences in 1905 would likely have understood. Those watching the film in 1909 or in the immediate years that followed might well have read the film in a similar manner, but with the additional context of $A$ Fool There Was and the later vampire dances.

How is it that scholars searching for early examples of screen vampires have not recognized one in Loïe Fuller? The answer probably resides in its title, which simultaneously headlines a celebrity and yet obscures specific content. Rather than being a misreading of a film, here is a surviving film that has not be read in the modern period, at least in the context of horror and vampirism.

Nevertheless, Loïe Fuller is quite possibly the first vampire film in cinema history. It drew upon and deployed the supernatural character of earlier folklore and literature and stage dances, while simultaneously invoking the "vamp" tradition as well. The screen's inaugural vampire marked the convergence of various traditions, making it a particularly complex entity: La danse macabre et la dance érotique. As Petr Malék has argued, "the vampire becomes a metaphor of intertextuality" (2010, p 129).
Much the same could be said of the intertextuality and intermediality that is key to early cinema.

\section{Conclusion}

In Reading the Vampire, Ken Gelder (1994) provides the formulation "I know there are no vampires ... but I believe in them" (p 53). In Bram Stoker's novel Dracula, Van Helsing asks Dr. Seward to "believe in things that you cannot." The undead are not inscrutable, but they are difficult to comprehend and challenging to understand, much in the same way that narratives in early moving pictures have occasionally seemed ambiguous and even elusive to viewers, not only at the time, but also to the present day.

In terms of vampires onscreen, it seems apparent that $L a$ légende du fantôme/Legend of a Ghost simply fooled one viewer in 1908, just as Le manoir du diable/The Devil's Castle has fooled many viewers in recent decades. Neither features a vampire. To say they do constitutes misreadings of the two films. And yet, to rephrase Van Helsing, audiences sometimes wish to believe in things they should not. After all, a number of critics have incorrectly taken the footage projected at the Cinématographe in Bram Stoker's Dracula to be authentic imagery filmed during the early cinema period, not simulacra created by Francis Ford Coppola, which it very definitely is (Cordell, 2013).

The first American-made film to reference supernatural vampires explicitly might well have been episode six of The Exploits of Elaine. At any rate, the film was but one of many early moving pictures that directly or indirectly used vampirism as a metaphor. They began at least as early as 1908 with Vampires of the Coast and continued through A Fool There Was (Fox, 1915) and well beyond. ${ }^{8}$ The Exploits of Elaine deserves recognition in a discussion of vampire cinema, but not necessarily more so than those inspired by Burne-Jones and Kipling. Indeed, The Vampire's metaphorical status arguably positions it nearer to the world of Burne-Jones than to Stoker.

To the extent that a supernatural vampire appeared in any moving picture produced before 1915, it occurred in Loïe Fuller. In terms of its historical context and its narrative content, this seems to be an accurate reading. Loïe Fuller's title character possesses supernatural powers and very much appears to be part of a vampire dance tradition that predates the metaphorical worlds of Burne-Jones and Kipling, rooted instead in supernatural folklore. That said, the intentionality of the filmmakers remains unknown. And no period responses to the film have survived, making commentary about how audiences in America or elsewhere received the film in 1905 at best informed speculation. As a result, the title character of Loïe Fuller is difficult to fix, as if it is flickering with uncertainty between the projector and projected, between "vamp" and "vampire."

Such ambiguities mark early cinema, to be sure, as well as all of film history. Daniel Frampton rightly reminds us, "Everything in a film may be well interpretable, but not every formal moment has meaning, arbitrariness is always possible" (2006, p 180). Vampires and films remain elusive in the years after the early cinema period, at least on occasion. Viewers would generally agree that the character Ellen (Greta Shröder) collapses at the end of Murnau's Nosferatu, but not all perceive that she has died, for example. Even more opaque are the oneiric and enigmatic worlds of Vampyr (Dreyer, 1932) and Nadja (Almereyda, 1994). The Kingdom of Shadows reigns to the present, with vampires amongst its longstanding residents.

The cinema is not actually vampiric, of course, let alone supernatural, but it is easy to see why Coppola and Merhige and others have drawn the link between them. In Stoker's novel, Mina 
Harker records the destruction of Dracula in her diary: "the whole body crumbled into dust and passed from our sight." Written accounts of the vampire are all that remain, as Jonathan Harker observes at the end of the novel:

We were struck with the fact that, in all the mass of material of which the record is composed, there is hardly one authentic document! Nothing but a mass of typewriting, except the later note-books of Mina and Seward and and myself, and Van Helsing's memorandum. We could hardly ask anyone, even did we wish to, to accept these as proofs of so wild a story.

Vampires are not ineffable, but their codes of intelligibility are shifting and amorphous. Like the cinema, vampires onscreen and off are shadowy, crepuscular, and nebulous, thus causing us to project onto them.

Received: 21 August 2017 Revised: 14 October 2017 Accepted: 13 November 2017

Published online: 21 December 2017

\section{Notes}

1 Academic papers include Lyz Reblin. (2011) "Trio of Terror," e-Research: A Journal of Undergraduate Research, 2 (1). http://digitalcommons.chapman.edu/e-Research/vol2/ iss1/6; Websites include the South African Vampyre Culture Center. See https:// vampyreculturecenter.wordpress.com/vampyre-culture/vampyre-art-literature-music/ the-celluloid-vampiyre/. Accessed 10 Oct 2016. Another example would be House of Horrors.com. See "Fangs for the Memories: 13 Ghastly Films," http://www.

houseofhorrors.com/vampires.htm. Accessed 10 Oct 2016. Yet another example would be The Vampire Project. See "Introduction to Cinematic Vampires" at http:// thevampireproject.blogspot.co.uk/2009/01/introduction-to-cinematic-vampires.html. Accessed 10 Oct 2016.

2 In The Vampire Film: Undead Cinema (London: Wallflower Press, 2012) Jeffrey Weinstock notes that The Devil's Castle "has been described as the cinema's first vampire," but opts to refer to the character as a "devilish figure" (p 79).

3 Charles Musser, "The Travel Genre in 1903-1904: Moving Towards Fictional Narrative," in Early Cinema: Space, Frame, Narrative, edited by Thomas Elsaesser with Adam Barker (London: British Film Institute, 1990), p 130.

4 Ibid, p 131.

5 An Excursion to the Moon is available on the 2007 DVD Saved from the Flames: 54 Rare and Restored Films, 1896-1944. Los Angeles: Flicker Alley.

6 A copy of Legend of a Ghost under the title The Black Pearl is available on the 2012 DVD Fairy Tales: Early Colour Stencil Films from Pathé. London: British Film Institute.

7 Two years later, in The Dream Dance (1915), a man visits the Moulin Rouge and dreams a picture of a woman "comes to life and lures him into a wild vampire dance." See "The Dream Dance." June 19, 1915. Moving Picture World: 1986.

8 Other examples produced during the early cinema period include: The Vampire (Kalem, 1913), The Vampire of the Desert (1913), A Fool There Was (Lubin, 1914). The Vampire's Trail (Kalem, 1914), and Universal Ike, Jr., and the Vampire (Universal, 1914).

\section{References}

A Fool There Was. (1915). [film] USA: Frank Powell.

Abbott S (2007) Celluloid vampires: life after death in the modern world. University of Texas Press, Austin

Batllori JMM (2009) Segundo de Chomón and the fascination for colour. Film Hist 21(1):94-101

Borton, T and D (2014) Before the movies: American magic-lantern entertainment and the nation's first green screen artist, Joseph Boggs Beale. John Libbey, New Barnet, Herts

Browning JE (2009) Introduction: documenting dracula and global identities in film, literature, and anime. in draculas, vampires, and other undead forms: essays on gender, race, and culture. Browning JE, Joan CE, (Kay) Picart (eds) Scarecrow, Lanham, Maryland, pp 9-22

Complete Catalogue of Lubin's Films (1903) Philadelphia: S. Lubin. A guide to motion picture catalogs by American producers and distributors, 1894-1908: A Microfilm Edition. 1985. New Brunswick: Rutgers University Press, Reel 3
Cordell SA (2013) Sex, terror, and Bram Stoker's Dracula: Coppola's reinvention of film history. Neo-Vic Stud 6(1):1-21

Edison Films, No. 94. (1900) Orange, New Jersey: Edison Manufacturing Company, March 1900. A guide to motion picture catalogs by American producers and distributors, 1894-1908: A Microfilm Edition. 1985. New Brunswick: Rutgers University Press, Reel 1

Elsaesser T (1990a) Afterword, In: Elsaesser T, Barker A (eds) Early Cinema: Space, Frame, Narrative. British Film Institute, London, pp 403-413

Elsaesser T (1990b) Introduction, In: Elsaesser T, Barker A (eds) Early Cinema: Space, Frame, Narrative. British Film Institute, London, pp 11-30

Excursion dans la lune. (1908). [film] France: Segundo de Chomón.

Flynn JL (1992) Cinematic vampires: the living dead on film and television, from The Devil's Castle (1896) to Bram Stoker's Dracula (1992). McFarland and Company, Jefferson, North Carolina

Frampton D (2006) Filmosophy. Wallflower, London

Fuller L (1913) Fifteen years of a dancer's life, with some account of her distinguished friends. Small, Maynard \& Company, Boston

Gelder K (1994) Reading the vampire. Routledge, New York, NY

Gunning T (1990a) The cinema of attractions: early film, its spectator and the avant-garde. In: Elsaesser T, Barker A (eds) Early Cinema: Space, Frame, Narrative. British Film Institute, London, pp 56-67

Gunning T (1990b) Primitive cinema: a frame-up? or the trick's on us. In: Elsaesser T, Barker A (ed) Early Cinema: Space, Frame, Narrative. British Film Institute, London, pp 95-103

Gunning T (1991) D.W. Griffith and the origins of American narrative film: the early years at biograph. University of Illinois Press, Urbana

Gunning T (1993) 'Now You See It, Now You Don't': The temporality of the cinema of attractions. Velv Light Trap 32:3-12

Gunning T (2003) Loïe Fuller and the art of motion: body, light, electricity, and the origins of cinema. In: Allen R, Turvey M (eds) Camera Obscura, Camera Lucida: Essays in Honor of Annette Michelson. Amsterdam University Press, Amsterdam, pp 75-89

Harding C, Popple S (1996) In the kingdom of shadows: a companion to early cinema. Cygnus Arts, London

L'homme dans la lune. (1899). [film] France: Georges Méliès.

L'arrivée d'un train en gare de La Ciotat. (1895). [film] France: Lumière.

La légende du fantôme. (1908). [film] France: Segundo de Chomón.

Le Chevalier des Neiges. (1912). [film] France: Georges Méliès.

La défaite de Satan. (1910). [film] France: Pathé Frères.

Le diable au couvent. (1900). [film] France: Georges Méliès.

Le fils du diable (1906). [film] France: Pathé Frères.

Leitch T (2011) Vampire Adaptation. Journal of Adaptation in Film \& Performance 4 (1): 5-16

List of New Films, American and Imported, K-0002 (1900) New York: American Vitagraph. A Guide to motion picture catalogs by American producers and distributors, 1894-1908: A Microfilm Edition. 1985. New Brunswick: Rutgers University Press, Reel4

Le manoir du diable. (1896). [film] France: Georges Méliès.

Le Voyage dans la lune. (1902). [film] France: Georges Méliès.

Les Vampires. (1915-16). [film] France: Louis Feuillade.

Les Vampires de la côte. (1909). [film] France: Pathé Frères.

Loïe Fuller. (1905). [film] France: Pathé Frères.

Lubin's Films (1908) Philadelphia: S. Lubin. A Guide to motion picture catalogs by American producers and distributors, 1894-1908: A Microfilm Edition. 1985. New Brunswick: Rutgers University Press, Reel 3

Malék P (2010) Adaptation as 'Reading Against the Grain': Stoker's Dracula. Illuminace 22: 101-129

Melton JG (2011) The vampire book: the encyclopedia of the undead. Visible Ink, Canton, Michigan

Musser C (1990a) The emergence of cinema: the American screen to 1907. University of California, Berkeley

Musser C (1990b) The travel genre in 1903-1904: moving towards fictional narrative. In: Elsaesser T, Barker A (ed) Early Cinema: Space, Frame, Narrative. British Film Institute, London, pp 127-131

Nosferatu. (1922). [film] Germany: F.W. Murnau.

Nead L (2007) The haunted gallery: painting, photography, film c. 1900. Yale University Press, New Haven, Connecticut

Posner Bcurator (2005) Unseen cinema: early American avant-garde film, 1894-1941. Image Entertainment, Chatsworth, California, DVD boxed set

Prince S (2004) Introduction: The dark genre and its paradoxes. In: Prince S (ed) The horror film, Rutgers University Press, New Brunswick, pp 1-11.

Satana, ovvero il dramma dell'umanità. (1912). [film] Italy: Ambrosio.

Shadow of the Vampire. (2000). [film] USA: E. Elias Merhige.

Singer B (2001) Melodrama and modernity: early sensational cinema and its contexts. Columbia University Press, New York

Testa B (1992) Back and forth: early cinema and the avant-garde. Art Gallery of Toronto, Toronto

The Exploits of Elaine. (1915). [film] USA: Pathé. 
The Forest Vampires. (1914). [film] USA: Domino.

The Gambler and the Devil. (1908). [film] USA: Vitagraph.

The Ghost Train. (1901). [film] USA: American Mutoscope and Biograph.

The Great Train Robbery. (1903). [film] USA: Edwin S. Porter.

The Vampire. (1910). [film] USA: Selig Polyscope.

Thompson K (1995) The limits of experimentation in Hollywood. In: Horak J-C

(ed) Lovers of cinema: the first American film Avant-Garde, 1919-1945.

University of Wisconsin Press, Madison, pp 67-93

Vampires of the Night. (1914). [film] USA: Greene Features.

Vasco, the Vampire. (1914). [film] USA: George Hall.

Wright D (2001, reprint of 1914 edition) Vampires and vampirism. Lethe, Maple Shade, New Jersey

\section{Data availability}

Data sharing not applicable to this article as no data sets were generated or analyzed during the current study.

\section{Additional information}

Competing interests: The author declares no competing financial interests.

Reprints and permission information is available online at http://www.nature.com/ reprints
Publisher's note: Springer Nature remains neutral with regard to jurisdictional claims in published maps and institutional affiliations.

cc) Open Access This article is licensed under a Creative Commons Attribution 4.0 International License, which permits use, sharing, adaptation, distribution and reproduction in any medium or format, as long as you give appropriate credit to the original author(s) and the source, provide a link to the Creative Commons license, and indicate if changes were made. The images or other third party material in this article are included in the article's Creative Commons license, unless indicated otherwise in a credit line to the material. If material is not included in the article's Creative Commons license and your intended use is not permitted by statutory regulation or exceeds the permitted use, you will need to obtain permission directly from the copyright holder. To view a copy of this license, visit http://creativecommons.org/ licenses/by/4.0/.

(c) The Author(s) 2017 